\title{
"Young and Green" a Study of Consumers' Perceptions and Reported Purchasing Behaviour towards Organic Food in Poland and the United Kingdom
}

\author{
Aleksandra Kowalska ${ }^{1} \mathbb{D}$, Monika Ratajczyk ${ }^{2} \mathbb{D}$, Louise Manning $^{3} \mathbb{D}$, Milena Bieniek $^{2, *(D)}$ \\ and Radosław Mącik ${ }^{2}$ (D) \\ 1 Institute of Economics and Finance, Maria Curie-Skłodowska University, pl. Marii Curie-Skłodowskiej 5, \\ 20-031 Lublin, Poland; aleksandra.kowalska@umcs.lublin.pl \\ 2 Institute of Management and Quality Sciences, Maria Curie-Skłodowska University, pl. Marii \\ Curie-Skłodowskiej 5, 20-031 Lublin, Poland; monika.ratajczyk@umcs.pl (M.R.); \\ radoslaw.macik@umcs.pl (R.M.) \\ 3 School of Agriculture, Food and the Environment, Royal Agricultural University, Stroud Road, \\ Cirencester GL7 6JS, UK; louise.manning@rau.ac.uk \\ * Correspondence: milena.bieniek@umcs.lublin.pl
}

check for updates

Citation: Kowalska, A.; Ratajczyk, M.; Manning, L.; Bieniek, M.; Mącik, R. "Young and Green" a Study of Consumers' Perceptions and Reported Purchasing Behaviour towards Organic Food in Poland and the United Kingdom. Sustainability 2021, 13, 13022. https://doi.org/ $10.3390 /$ su132313022

Academic Editor: Rosa Maria Fanelli

Received: 22 October 2021

Accepted: 22 November 2021

Published: 24 November 2021

Publisher's Note: MDPI stays neutral with regard to jurisdictional claims in published maps and institutional affiliations.

Copyright: (c) 2021 by the authors. Licensee MDPI, Basel, Switzerland. This article is an open access article distributed under the terms and conditions of the Creative Commons Attribution (CC BY) license (https:/ / creativecommons.org/licenses/by/ $4.0 /)$.

\begin{abstract}
Globally, the organic food market is the most successful green market. Young consumers, the decision-makers of the future, are perceived as being more environmentally concerned than older cohorts. The aim of this study was to consider young consumers' attitudes and behaviours concerning organic food, where the organic food market in the UK is more mature than in Poland. Empirical research was conducted using a web-based survey questionnaire (CAWI) with consumers $(n=973)$ in both countries. The associations between four constructs (general pro-social attitudes, green consumption values, receptivity to green communication, and buying behaviour) were considered using CB-SEM. We extended the model with two new constructs to explain young consumers' purchases of organic food. UK respondents are significantly more conscious green consumers with higher environmental attitude intensity than Polish residents. Intensity of pro-environmental attitude components influences directly and indirectly the choice of organic food. People with a higher intensity of pro-environmental attitudes are significantly more likely to choose organic food. Perception of organic food influences purchases only in Poland. The components of proenvironmental attitudes and perception of organic food alone do not explain the variability in behaviour, despite a good fit of the model. This suggests that other independent variables may be of influence.
\end{abstract}

Keywords: young consumers; pro-environmental attitudes; sustainable consumption; organic food; antecedents of green consumption

\section{Introduction}

In the Anthropocene, a geological epoch, the resource-intensive lifestyle of consumers, consumption-related choices, and behaviour have been recognised as key drivers of environmental degradation and unsustainable development [1-4]. Unsustainable development practices have resulted in global environmental changes, including poorly planned urbanisation, climate change, deforestation, changes in hydrological systems, land degradation, ecosystem impairment, and loss of biodiversity [5-9]. These changes have had a tremendous impact on ecosystem health and the physical and mental health of global society, affecting the well-being of people [10] and their economies.

Since the United Nations (UN) Earth Summit in Rio de Janeiro in 1992, numerous governments, multilateral non-government organisations, and scientific societies have sought to facilitate less resource-intensive personal consumption and to ensure prosperity but not exceeding planetary boundaries [11]. Agenda 21 indicated that "while poverty results 
in certain kinds of environmental stress, the major cause of the continued deterioration of the global environment is the unsustainable pattern of consumption and production, particularly in industrialised countries, which is a matter of grave concern, aggravating poverty and imbalances" [12].

Food systems, considered as all elements and activities that relate to production, processing, distribution, preparation, and consumption of food, support human health and environmental sustainability $[13,14]$. However, they create the largest, human-related pressure on Earth [14]. The objective of the UN Sustainable Development Goal (SDG) 12 is to "ensure sustainable consumption and production patterns", which means that consumers should shift to nutritious and safe diets with a lower environmental footprint. In addition, producers need to grow more food for an expanding global population, while reducing negative environmental impacts [15] — a tall order. This transition to healthy and sustainable diets, involving multiple stakeholders including consumers, is necessary for achieving the UN SDGs which seek to eliminate poverty, hunger, and malnourishment and to safeguard the planet and ensure social and economic well-being for all [14].

One option for more sustainable food production is organic production, described in Regulation (EU) 2018/848 of the European Parliament and of the Council of 30 May 2018 on organic production and labelling of organic products and repealing Council Regulation (EC) No. 834/2007 [16] as

"a sustainable management system consisting of the production of a wide variety of high-quality food and other agricultural and aquaculture products that respond to consumers' demand for goods that are produced by the use of processes that do not harm the environment, human health, plant health or animal health and welfare."

Organic production was the focus of this research, including its relevance to young consumers as an option for demonstrating sustainable consumption when considering food.

Young consumers are of particular relevance for sustainable consumption researchers, policymakers, and educators since the spending power of this group is rapidly expanding, and as a result, the potential for positive sustainability impacts resulting from their consumption choices is also expanding [2]. Generation Z (Gen Z) is the consumer group with the greatest spending power $[17,18]$. However, as far as the number of consumers is concerned, Generation Y (Gen Y) is the most numerous [19]. The Pew Research Center considers anyone born between 1981 and 1996 as a Millennial or part of Gen Y (also referred to as the Net Generation, Generation Next, Millennials, Trophy Kids, Generation www, or Echo Boomers). Anyone born from 1997 onward is identified as a member of Gen Z (also known as the Post-Millennials, Gen Z, Gen Zets, iGen, Centennials, Homelanders, Zoomers, Children of Internet, Media Generation, .com Generation, Google Generation, iGen, or Instant Online) [20-23].

Gen $Y$ and Gen $Z$ consumers are tech-savvy and constantly digitally connected. Additionally, the use of electronic word-of-mouth and social media has influenced their buying behaviour $[17,24]$. Young consumers, as natives in a globalised digital world, are similarly conditioned across cultures, nationalities, and ethnicities, but their consumption-related behaviours are at the same time impacted by different cultural, historical, and individual situations [25]. This literature frames the empirical study. The general research question considered in this study was:

Are there differences between young consumers' attitudes and behaviour concerning organic food in Poland and the UK?

There are diverse theories, models, and frameworks which help understanding of green consumer behaviour, focusing on the value-attitudes/norms-intentions-behaviour hierarchy, including the theory of planned behaviour (TPB) $[26,27]$, theory of reasoned action (TRA) [28], and the ecologically conscious consumer behaviour (ECCB) models [29]. Nonetheless, value-belief-norm (VBN) theory [30], rather than the TRA [28] or TPB [27], may be more useful to researchers seeking to explain green behaviour because the VBN considers both altruistic and/or rational value-driven beliefs and norms [31]. The VBN proposes that consumers' environmental behaviours are determined by a combination of 
moralistic (altruistic) or personal (economic or social) values and norms [31]. Do Paço et al. [32] position a model of green consumer behaviour that integrates social concerns and attitudes as well as external influences (the influence of green marketing). Using a questionnaire on-line survey, this study examined links between constructs to first test the model of do Paço et al. [32] for young consumers from the UK and Poland in order to evaluate its applicability in different generational cohorts and countries. Second, this research intended to expand the prevailing model of green consumer behaviour through examining both the direct and indirect impact of modelling constructs (general pro-social attitudes, green consumption values, receptivity to green communication, buying behaviour) on the perception of organic food and purchasing behaviour in the organic food market.

The empirical research following questionnaire design was exploratory in nature, and therefore, research questions rather than research hypotheses were formulated.

RQ1: Is the scale verifying the intensity of pro-environmental attitudes equally valid for Polish and UK sample cohorts?

RQ2: As the UK has a more mature organic food market, are there greater proenvironmental attitudes shown in the UK compared with Poland?

RQ3: Do pro-environmental attitudes influence the choice of organic food?

RQ4: Does the perception of organic food influence the choice of organic food?

\section{Literature Review}

Organic foods can be defined as foods grown with the aim of conserving soil, water, and air and minimizing environmental impact. The use of synthetic fertilisers and chemical crop protection products, prophylactic use of antibiotics, use of genetically modified organisms (GMOs), or ionising radiation are prohibited [33-35]. However, some authors claim that the ecological benefits of organic farming are only partly beneficial, as more land is required for the same net output because of lower yields [36-41]. Organic agriculture may be "less polluting" but only in terms of per unit of land, but not per unit of output [42]. While Meemken and Qaim [42] (p. 39) claim that "organic farming is not the paradigm for sustainable agriculture and food security", the International Federation of Organic Agriculture Movements (IFOAM) asserts that organic agriculture contributes to achieving numerous SDGs by ensuring (i) healthy lives and promoting well-being; (ii) availability and sustainable management of water; and (iii) protection, restoration, and promotion of sustainable land management and preservation of biodiversity [43].

There are several studies based on life cycle assessment (LCA) analysis seeking to assess the environmental impact of food consumption and proposing the most effective ways to reduce impact through minimising meat consumption, refusing air-transported food, and preferring organic products [36,44]. Seufert, Ramankutty, and Mayerhofer [45] advocate increasing emphasis on environmental best management practices in organic regulations across the world (including leguminous crops in rotations, the use of cover crops, plant diversification schemes, improving genetic diversity in crops, the use of conservation tillage, and greater integration of mixed farming systems (crops and livestock)). Delivering environmental sustainability with regard to the atmosphere, water, and soil can be achieved only if a sustainable pattern of production (sources) and consumption (sinks) is maintained [46].

The evolution of consumers' concerns towards the environment has fostered the development of a green products market, especially in the United States (US) and Germany $[47,48]$, which is seen as a proxy for green food production. These two countries had the largest organic markets worldwide in 2019 and for several preceding years. The US organic market in 2019 was EUR 44.7 billion, representing $42 \%$ of the global organic food market; and the German organic market was EUR 12.0 billion, representing $11 \%$ of the global organic food market [49] (p. 22). Thøgersen [50] rightly emphasized that the "organic food market is probably the most successful green market worldwide". The global market for organic foods expanded over 7-fold between 2000 and 2019; the compound 
annual growth rate (CAGR) of global organic retail sales within the studied period was 7.7\%, with global retail sales reaching EUR 106.4 billion in 2019 [51]. Over the past twenty years, the market for organic foods has centred on North America and Europe (Figure 1). Indeed, the two regions comprised $87.6 \%$ of global organic retail sales in 2019 . However, over the past fifteen years, the demand for organic food has been rapidly growing in Asian countries, in China in particular [52]. China was the fourth largest single market for organic foods in 2019 with retail sales of EUR 8.5 billion, after France (EUR 11.3 billion) [49] (p. 22).

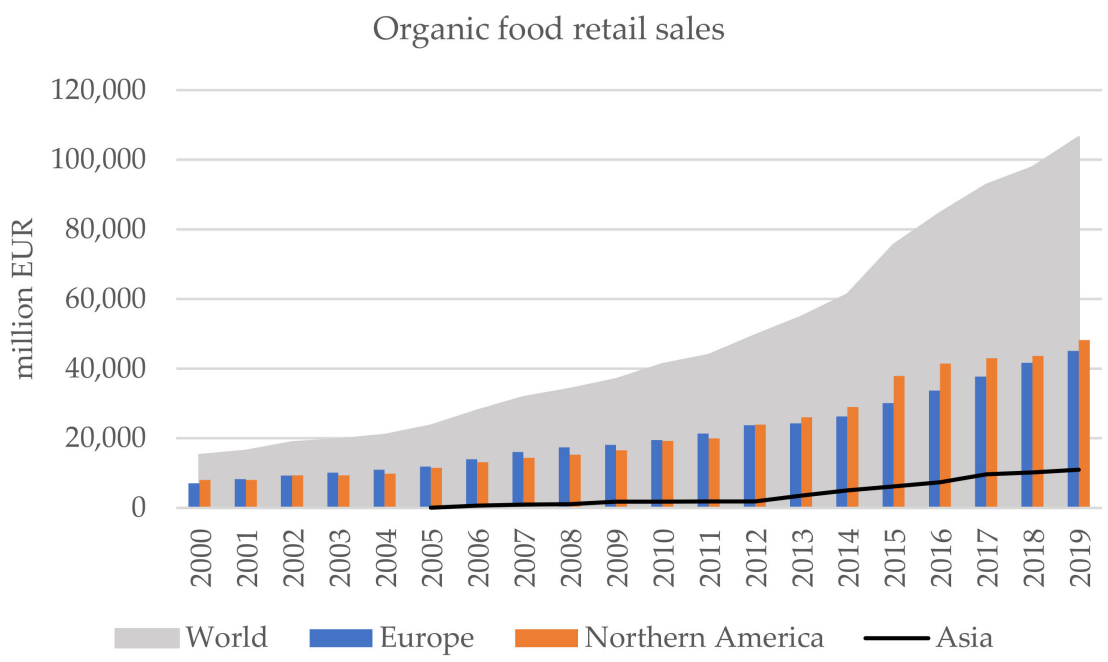

Figure 1. Organic food retail sales in the top-performing regions of the world over the 2000-2019 period (Source: Own elaboration based on [51]).

\subsection{Explaining Green Buying Behaviour}

The green consumer is defined as an individual who purchases products with the aim of minimising harm to the environment [52]. The phenomenon of green consumption must be considered within the wider range of terms, including sustainable consumption, ethical consumption, moral consumption, and anti-consumption [53]. Sustainable consumption behaviour includes actions such as purchasing sustainable and fair trade goods (including energy-efficient appliances, products packaged in reusable containers, biodegradable products, commodities made with recycled materials, products that are not tested on animals, durable products, and organic food), separating and recycling household waste, adopting a voluntary simplified lifestyle, switching to less environmentally impactful transport modes, investing in sustainable funds, etc. [1,32,54-56].

Even though the green purchasing behaviour of consumers is related to meeting both basic and higher needs, it is essential for sustainable development to improve the green attributes of food and other consumer goods [57]. Engaging in green consumption provides a dual benefit of consumers' improved health and the opportunity to contribute to environmental sustainability [58]. The theoretical model used in this study is based on a set of buying behaviour antecedents-namely, the general pro-social attitudes (the tendency of individuals to consider the rights and obligations and the wellbeing of others, i.e., to feel empathy), green consumption values (the tendency to prioritise environmental outcomes via purchasing and consumption behaviour), and receptivity to green communication (the attention paid to, or feelings about, green messaging and advertising) which contribute to buying behaviour [see 32].

\section{General pro-social attitudes}

Consumers are regarded as the key to sustainable development since their behaviours affect the way companies operate [59]. Spielmann [60] (p. 1) indicates that "a common explanation for the growth of green consumption is the positive social and moral standards that it represents: doing what is best for the greater good, making the world a better place for tomorrow, etc.". Some consumers have an intrinsic motivation (called warm glow) to 
act or respond altruistically, i.e., pro-socially or pro-environmentally, where there is an association with the purchase of multiple sustainable products [60]. Do Paço et al. [32] adapted the general pro-social attitudes scale from Osgood and Muraven [61] due to its focus on altruistic behaviours commonly linked with environmental factors.

A crucial reason why people purchase organic food is a belief that food choice has environmental and ethical implications [62-66]. Environmental concern, defined as consumers' recognition of ecological problems and readiness to solve them, has been recognised as an important motivating factor and driver of positive consumer attitudes towards organic food $[48,67]$. Since concern for the environment generates benefits for the entire society, environmental motives that influence organic consumers can constitute altruistic factors, orienting attitudes towards organic purchases [68].

\section{Green consumption values}

Biswas and Roy [69] studied across consumer cohorts the impact of consumption values (functional value, social value, environmental value, conditional value, and knowledge value) on sustainable consumption behaviour. The results of the research supported the hypothesis that there is an association between sustainable consumption behaviour and consumer environmental values. Green consumption values and consumer attitudes towards sustainable food logistics influence green purchase intention and motivate environmentally conscious behaviour [70]. Green consumption values inform greater preference for green products, but this is mediated by factors such as aesthetic appeal [71]. Do Paço et al. [32] applied the green consumption values scale developed by Haws et al. [71], examining how consumers' green consumption values affect consumer' responses to environmentally based marketing.

\section{Receptivity to green communication}

Green marketing consists of "actions directed to all consumers and incorporates a broad range of marketing activities (e.g., price, planning, process, production, promotion, and people) designed to demonstrate the firm's goal of minimising the environmental impact of its products and services" [72] (p. 1850). Green marketing contains a promise of delivering both commercial and environmental sector benefits. Green advertising, a crucial aspect of green marketing, promotes aspects of greenness associated with products or services [73], but the degree of consumer engagement can vary [74-76]. Furthermore, functional green advertising appeals (based on providing information about relative environmental benefits that a brand offers as compared to its non-green competitors) should be more effective for technology-intensive products, and emotional green advertising appeals (based on emotional benefits such as customers' feeling of well-being (warm glow) associated with acting in an altruistic way) should be more effective for technological non-intensive products [77].

Labelling on packaging is an important marketing tool used to inform consumers about the nature of green products. In environmental consumerism, labelling is effective in stimulating positive pro-environmental attitudes and in fostering the selection of green products over conventional ones [78,79]. Even though labels can be effective in engaging consumers who have little concern about the environment, they lose their effect when the environmental concern is already high [78]. Furthermore, external influences that have an impact on stakeholders' perceptions of corporate environmental responsibility include greenwashing practices, the misleading communication practice associated with environmental issues [80]. To access receptivity to green communication, do Paço et al. [32] applied the scale developed by Bailey et al. [75].

\section{Buying behaviour}

The fourth construct in the model utilised in this study was green buying behaviour, which includes enacting sustainable consumption practices, such as increasing spending on green products and supporting green companies [32,81]. Green consumers may be influenced by other factors too, including the range of green products offered, the availability and validity of information, and communication and claims made that are associated with the product [32]. In this regard, we share the view of Thamthanakoon et al. [82] who 
claim that "past behaviour exerts influence on intention indirectly, through the outcomes of the appraisal of the channel used, typically including attitude toward and trust in the channel" (p. 4). To access buying behaviour, do Paço et al. [32] applied ten items from the ECCB scale [29] covering issues such as right packaging, polluting, or recycling.

\subsection{Organic Food Buying Behaviour: Antecedents and Outcomes}

Buying behaviour is now considered with a focus on organic food. The European average per capita spend on organic food was EUR 55.8 in 2019 and varied from country to country (Figure 2). In 2019, organic food purchases were the highest in terms of per person spending in Denmark, Switzerland, Luxemburg, Austria, and Sweden with EUR 214-344 spent per person per year [51]. The consumer spending on organic food in the UK increased by $25 \%$ in the last decade but remained below the European average at EUR 39 per capita in 2019 [51]. Eastern European countries showed the lowest spending on organic food, with Poland having per capita spend of EUR 8 in 2019 (compared with EUR 2 in 2010). This highlights that, although the UK has a well-established organic market, UK and Polish consumers are "reticent purchasers" amongst the European population, making them worthy of study.

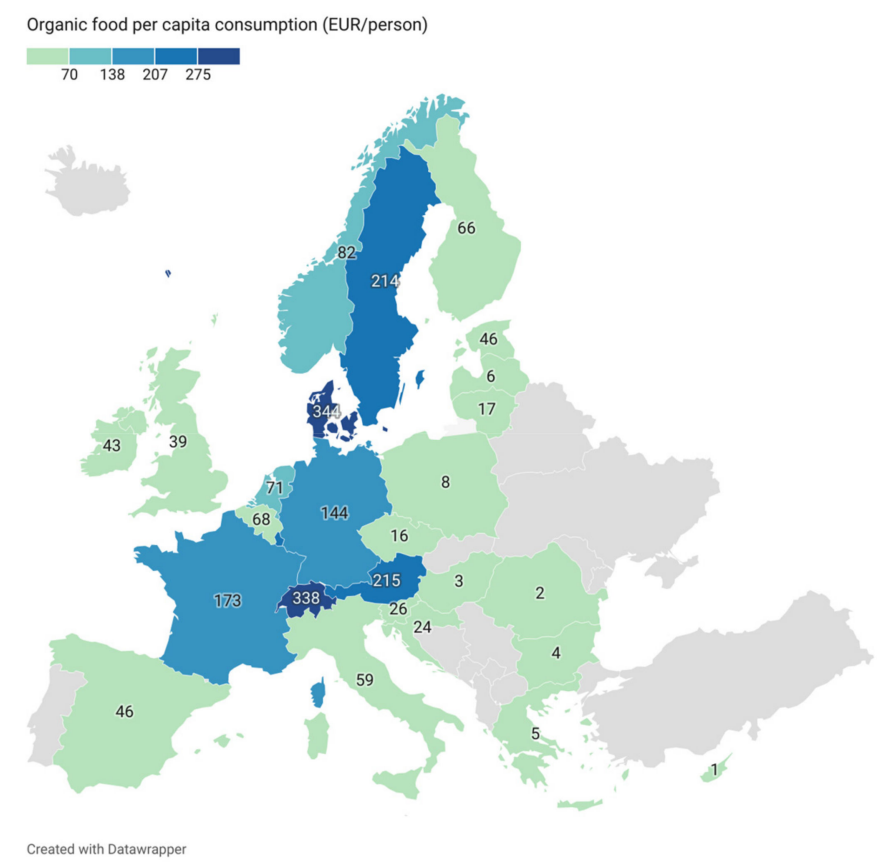

Figure 2. A per capita spending on organic food in selected European countries in 2019 (Source: own elaboration based on [51]).

The barriers to the development of the organic food market appear to vary across the world, stemming from historical, cultural, political, social, and economic issues. Rana and Paul [48] reviewed and interpreted 146 research articles published in the 1985-2015 time period in English which were either listed in the Social Science Citation Index or in Scopus in order to consider the headline factors influencing the transition in consumer attitudes towards organic food. Based on this systematic literature review, the important factors that were determined as affecting attitudes and demand for organic food are: accessibility/ease of purchase, animal welfare, consumer trust in labelling and certification, economic acquirability of organic food, environmental considerations, ethical commitment, fashion, food habits and lifestyle of consumers, having young children, health consciousness, household disposable income, knowledge of the organic production method, marital status, price of organic food compared with conventional food, quality and safety issues, and supporting local agriculture. 
Kushwah, Dhir, Sagar, and Gupta [83] stated in their review article that across cultures most of the barriers to organic food consumption were common, i.e., limited visibility, trust, choice, availability, knowledge and information, convenience, higher price, sensory cues, scepticism, and doubts concerning labelling and certification. A survey of 1000 Polish consumers identified the key barriers to growth in the organic food market as high prices, then insufficient consumer knowledge and low product availability [84]. However, recent marketing research conducted in Czech Republic in 2019 showed that price was no longer a decisive factor for the purchase of organic food [85].

Massey, O'Cass, and Otahal [86] categorised factors motivating the purchase of organic food through aligning them with credence attributes (intrinsic - health, quality, safety, nutritional aspects and extrinsic — environmental impact, animal welfare, and production standards), search attributes (price, availability, and appearance), and experience attributes (organoleptic factors). Credence attributes cannot be assessed or determined by the consumer in the purchasing, preparation, or consumption phase, but they are important in the consumer's purchase decision-making [87]. Consumers give high importance to the search and experience attributes [86], which can be discovered prior and after consumption, and they make repeat purchases of food products connected with good experiences over time. Thus, past consumption drives consumer attitudes towards organic food purchase intention [88].

Health of individuals and of their families is a second major factor that influences organic food purchase decisions and willingness to pay (WTP) for food certified as organic [37,66,89-92]. Health consciousness can be regarded as a more egoistic motivation determining organic food behaviour because it mainly benefits the individual [93]. Numerous studies indicate that organic food is healthier compared with conventional food due to the overall composition, including the nutrient content of the food and maximum tolerance level of certain contaminants [94,95]. The effect of various factors should be considered when evaluating the health outcomes of people consuming organic food, e.g., healthier lifestyle [94]. However, a direct cause-effect relationship between organic food consumption and consumers' health is still under debate $[96,97]$. The methodology is now discussed.

\section{Materials and Methods}

The study presented herein is a part of a project supported by the National Science Centre, Poland, under grant no. 2019/35/D/HS4/00801 titled "The effect of demand uncertainty in supply chain modelling with emphasis on additive uncertainty". The quantitative research was carried out using a web-based survey questionnaire (CAWI) on a total sample of 973 individuals from Gen Z (18-23 years of age) and Gen Y (24-39 years of age), among consumers who were either Polish or UK residents. Young adults were selected for this in-depth analysis as youth are perceived as being more concerned about current environmental issues than older cohorts [98,99]; hence, considering their ability to make informed choices of eco-friendly products is of interest. Furthermore, young consumers, born after 1981, are the decision makers of the future who make up the largest proportion of registered voters in many countries [98].

Data collection was conducted through a survey in two culturally and socioeconomically distinct countries, i.e., Poland and the UK, to examine the applicability of the do Paço et al. [32] model to carry out an in-depth analysis of young and green consumers' perception and reported purchases of organic food. The survey was conducted in two languages, Polish and English, depending on the respondents' country of residence, between December 2020 and February 2021, i.e., during the COVID-19 pandemic and under relatively deep lockdowns in both countries. The questionnaire was approved by the Research Ethics Committee at UMCS (Poland) and the Royal Agricultural University Ethics Committee (UK) in November 2020. The average completion time was 16 min 38 s. All respondents participated in the study on a voluntary basis. A prerequisite for successful recruitment was to belong to Gen Y or Gen Z. The link to the questionnaire was primarily disseminated 
among the students of all five state universities in Lublin (Poland) and in the UK, via a snowball process. The completion rate for the questionnaire was 55\% (3004 participants opened the first page of the survey questionnaire). Although the sample selection was non-random, most of the variables used in the analysis showed ex post randomness based on a series test. The analysis showed that only single survey items in both the Polish and UK sample did not show the nature of a random sample.

The questionnaire comprised 37 specific questions grouped into four sections on shopping habits relating to organic food (together with reasons for the lack of interest in organic food), perception of nine different types of food (including organic food), proenvironmental attitudes intensity, and demographic questions. The fully completed questionnaires and the questionnaires with rare missing data were included. The averages of all observations for a particular variable filled blank cells. This approach was followed by [100-102].

The scale proposed by do Paço et al. [32], containing 31 items grouped into four previously described dimensions (latent variables), was used in this study to measure the intensity of pro-environmental attitudes of young residents of Poland and the UK. In this study, scale items were verified on a 5-point Likert scale (a 7-point Likert scale was used in the original study by do Paço et al. [32]). All dimensions achieved the required reliability.

We based the verification of RQ1 on structural equation modelling (SEM) (IBM AMOS 27), while with RQ2 by comparing the average intensity of attitudes in both national groups.

We also used SEM to verify RQ3 and RQ4. More precisely, we extended the do PaçO et al. [32] model by adding to this model two latent variables (organic food perception and organic food purchase). The verification of RQ3 and RQ4 was completed on the basis of our research questionnaire. The scale measuring organic food perception consisted of six variables in the format of a unipolar semantic scale and verified the perception of the following aspects: healthiness (unhealthy-healthy), trustworthiness (untrustworthy-trustworthy), quality (not good quality-good quality), control system (not strictly controlled-strictly controlled), authenticity (inauthentic-authentic), and safety (not safe-safe). The other two variables used in the study, affordability and availability, formed a separate aspect of this perception and were therefore excluded.

The organic food purchase construct was created from two variables: reported organic food purchases (dichotomy scale-buys/does not buy) and reported organic food purchase frequency (an index counting the frequency of purchase of each of the 19 organic product categories). We asked the respondents about the frequency of purchase of organic food products from three categories, i.e., virtue products ("shoulds"), including dairy products, fresh fruit and vegetables, bread, eggs, groats, olive oil, frozen fruit and vegetables; vice products ("wants"), including chocolate, cookies and pastries, wine, beer, crisps and salty biscuits, sweets and candy, soft drinks; and neither vice nor virtue organic food products, including butter and margarine, meat and meat preparations, rice, pasta, coffee or tea [103].

The Polish and UK sample sizes were different; however, direct comparisons were considered valid see [104]. The Polish sample (PL sample) was assumed to be the main research group, and the UK sample was mainly a replication of the sample for the model of do Paço et al. [32] (questionnaires administered to the UK sample and those used by do Paço et al. [32] were drawn up in English). Table 1 presents the structure of both samples. The demographic profile of the consumers surveyed shows that women outnumbered men in both samples. About two-thirds of participants residing in Poland were members of Gen Z, whereas over $60 \%$ of respondents from the UK were members of Gen Y. Many more of the respondents surveyed in the UK did not describe themselves as British than the equivalent in the Polish cohort, which is justified by the fact that foreign residents form a much larger group within the UK population (9\%) [105] than within Polish society $(0.9 \%)$ [106]. 
Table 1. Demographic characteristics of the investigated samples.

\begin{tabular}{cccc}
\hline & & PL Sample & UK Sample \\
\hline Research sample & $\mathrm{N}$ & 812 & 161 \\
Gender & Female & $72.5 \%$ & $75 \%$ \\
& Male & $27.5 \%$ & $25 \%$ \\
Age & Generation Y & $33.9 \%$ & $62.1 \%$ \\
& Generation Z & $66.1 \%$ & $37.9 \%$ \\
Place of residence & Lublin/Cirencester & $39.8 \%$ & $19.9 \%$ \\
& Other town in PL/UK & $58.7 \%$ & $68.3 \%$ \\
Nationality & Other town outside PL/UK & $1.5 \%$ & $11.8 \%$ \\
& Polish/British & $93.7 \%$ & $65.2 \%$ \\
& Other & $6.3 \%$ & $34.8 \%$ \\
\hline
\end{tabular}

Source: Own research.

\section{Results}

The study verified whether the scale's dimensionality was identical to the research of do Paço et al. [32] concerning the language-adapted version (Polish) and the original version used in the UK research. Exploratory factor analysis (principal components method with varimax rotation with Kaiser normalisation) was carried out. It revealed that five factors were valid in the sample ( $64.2 \%$ of the variance was explained). Two statements (B1- "I try to buy energy-efficient products" and appliances and B10- "I buy high-efficiency light bulbs to save energy") formed a separate dimension in both groups. Consequently, a decision was made to exclude them from further analyses. The PCA results were confirmed by the confirmatory factor analysis (CFA). At the same time, it was noted that loadings for certain items in the PCA analysis (Table 2) were lower than the required 0.7 (especially for V4- "I am concerned about wasting the resources of our planet" and B6- "I use environmentally friendly soaps and detergents"). However, these statements were considered important for further analysis; thus, they were retained. The reliability of the whole scale was very good. Cronbach's alpha for the whole scale was 0.948 (0.946 in the Polish sample and 0.945 in the British one). Reliability for individual dimensions is presented in Table 2.

Using the non-parametric Spearman correlation, it was shown that there was a strong statistically significant correlation between a specific dimension and the full scale with slightly stronger correlation in the Polish sample (Table 3). Weaker correlations between any two dimensions than correlations of a specific dimension with the full scale assessed the discriminant validity of those dimensions. It should be noted that the general pro-social attitudes dimension had the slightest association with organic food buying behaviour. In contrast, green consumption values had the strongest association with the buying behaviour and receptivity to green communication.

The next step was to replicate the do Paço et al. [32] model in both samples via structural equation modelling with latent variables, as both antecedents and consequences could be assessed in such an approach. Model structure treated general pro-social attitudes as an antecedent of green consumption values that explained buying behaviour. Receptivity to green communication mediated the relationship between green consumption values and buying behaviour (Figure 3). It should be noted that because do Paço et al. [32] used PLS-SEM estimation in their study, the values of path coefficients were not directly comparable between studies, as here the covariance-based structural equation modelling (CB-SEM) approach was used (Model 1-Figure 3). The associations between general prosocial attitudes and green consumption values, green consumption values and receptivity to green communication, and green consumption values and buying behaviour were statistically significant (at $p<0.01$ ). In contrast, the association between receptivity to green communication and buying behaviour was not statistically significant for the UK cohort, but it was statistically significant for the Polish one (PL $p=0.000$, UK $p=0.076$ ) (Figure 3). The impact of the receptivity to green communication on buying behaviour was 
not statistically significant in the do Paço et al. [32] research, as it was in the case of the UK sample in our study.

Table 2. Factor validity and reliability of the pro-environmental attitudes scale.

\begin{tabular}{|c|c|c|c|c|c|}
\hline \multirow[b]{2}{*}{ Variable } & \multirow[b]{2}{*}{ Item } & \multicolumn{2}{|c|}{$\begin{array}{l}\text { PCA's Factor } \\
\text { Loadings }\end{array}$} & \multicolumn{2}{|c|}{$\begin{array}{l}\text { Scale Reliability } \\
\text { (Cronbach's Alpha) }\end{array}$} \\
\hline & & PL & UK & PL & UK \\
\hline \multicolumn{6}{|c|}{ General pro-social attitudes } \\
\hline A1 & It is important that others are happy. & 0.736 & 0.704 & \multirow{6}{*}{0.904} & \multirow{6}{*}{0.924} \\
\hline A2 & It is important to help someone who needs it. & 0.64 & 0.762 & & \\
\hline A3 & I want to help others. & 0.614 & 0.8 & & \\
\hline A4 & The well-being of others is important. & 0.735 & 0.742 & & \\
\hline A5 & The needs of others are important. & 0.662 & 0.809 & & \\
\hline A6 & It is important that all people are happy. & 0.685 & 0.694 & & \\
\hline \multicolumn{6}{|c|}{ Green consumption values } \\
\hline $\mathrm{V} 1$ & $\begin{array}{l}\text { It is important to me that the products I use do not harm } \\
\text { the environment. }\end{array}$ & 0.64 & 0.715 & \multirow{6}{*}{0.885} & \multirow{6}{*}{0.872} \\
\hline $\mathrm{V} 2$ & $\begin{array}{l}\text { I consider the potential environmental impact of my actions } \\
\text { when making many of my decisions. }\end{array}$ & 0.705 & 0.756 & & \\
\hline V3 & $\begin{array}{c}\text { My purchase habits are affected by my concern for } \\
\text { our environment. }\end{array}$ & 0.678 & 0.698 & & \\
\hline $\mathrm{V} 4$ & \multirow{3}{*}{$\begin{array}{l}\text { I am concerned about wasting the resources of our planet. } \\
\text { I would describe myself as environmentally responsible. } \\
\text { I am willing to be inconvenienced in order to take actions that are } \\
\text { more environmentally friendly. }\end{array}$} & 0.59 & 0.489 & & \\
\hline V5 & & 0.622 & 0.688 & & \\
\hline V6 & & 0.575 & 0.657 & & \\
\hline \multicolumn{6}{|c|}{ Receptivity to green communication } \\
\hline $\mathrm{C} 1$ & I support brands that support the environment. & 0.6 & 0.612 & \multirow{9}{*}{0.932} & \multirow{9}{*}{0.937} \\
\hline $\mathrm{C} 2$ & $\begin{array}{l}\text { I tend to pay attention to advertising messages that talk about the } \\
\text { environment. }\end{array}$ & 0.707 & 0.703 & & \\
\hline $\mathrm{C} 3$ & $\begin{array}{c}\text { The use of green messages in ads affects my attitude toward } \\
\text { the ads. }\end{array}$ & 0.642 & 0.631 & & \\
\hline $\mathrm{C} 4$ & $\begin{array}{l}\text { I respond favourably to brands that use green messages in } \\
\text { their advertising. }\end{array}$ & 0.706 & 0.808 & & \\
\hline C5 & $\begin{array}{l}\text { I am the kind of consumer who responds favourably when } \\
\text { brands use green messages in their ads. }\end{array}$ & 0.695 & 0.835 & & \\
\hline C6 & I think that green advertising is valuable. & 0.721 & 0.746 & & \\
\hline $\mathrm{C} 7$ & Green advertising is a necessary form of advertising. & 0.651 & 0.637 & & \\
\hline $\mathrm{C} 8$ & $\begin{array}{c}\text { I am the kind of consumer who is willing to purchase products } \\
\text { marketed as being green. }\end{array}$ & 0.577 & 0.647 & & \\
\hline C9 & I tend to pay attention to green advertising messages. & 0.697 & 0.742 & & \\
\hline \multicolumn{6}{|c|}{ Buying behaviour } \\
\hline B1 & I try to buy energy-efficient products and appliances. & 0.759 & 0.565 & \multirow{9}{*}{$\begin{array}{c}0.89 \\
(0.886 \text { after } \\
\text { exclusion } \\
\text { of B1 and } \\
\text { B10 items) }\end{array}$} & \multirow{9}{*}{$\begin{array}{c}0.891 \\
(0.881 \text { after } \\
\text { exclusion of } \\
\text { B1 and B10 } \\
\text { items) }\end{array}$} \\
\hline B2 & I avoid buying products that have excessive packaging. & 0.536 & 0.618 & & \\
\hline B3 & $\begin{array}{c}\text { When there is a choice, I choose the product that causes the } \\
\text { least pollution. }\end{array}$ & 0.616 & 0.621 & & \\
\hline B4 & I have switched products/brands for ecological reasons. & 0.635 & 0.708 & & \\
\hline B5 & $\begin{array}{l}\text { I make every effort to buy paper products made from } \\
\text { recycled paper. }\end{array}$ & 0.651 & 0.589 & & \\
\hline B6 & I use environmentally friendly soaps and detergents. & 0.522 & 0.444 & & \\
\hline B7 & $\begin{array}{l}\text { I have convinced members of my family or friends not to buy } \\
\text { products which are harmful to the environment. }\end{array}$ & 0.596 & 0.6 & & \\
\hline B8 & $\begin{array}{c}\text { Whenever possible, I buy products packaged in } \\
\text { reusable containers. }\end{array}$ & 0.564 & 0.682 & & \\
\hline B9 & I try to buy products that can be recycled. & 0.638 & 0.592 & & \\
\hline
\end{tabular}


Table 3. Correlation between dimensions of the pro-environmental attitudes scale.

\begin{tabular}{|c|c|c|c|c|c|}
\hline $\begin{array}{l}\text { Correlation } \\
\text { Coefficient }\end{array}$ & & $\begin{array}{c}\text { General } \\
\text { Pro-Social } \\
\text { Attitudes }\end{array}$ & $\begin{array}{c}\text { Green } \\
\text { Consumption } \\
\text { Values }\end{array}$ & $\begin{array}{l}\text { Receptivity to } \\
\text { Green } \\
\text { Communication }\end{array}$ & Buying Behaviour \\
\hline \multirow{3}{*}{ PL sample } & $\begin{array}{c}\text { Full scale (Pro-environmental } \\
\text { attitudes) }\end{array}$ & $0.593 * *$ & $0.834^{* *}$ & $0.832 * *$ & $0.800^{* *}$ \\
\hline & General pro-social attitudes & & $0.421^{* *}$ & $0.394^{* *}$ & $0.300 * *$ \\
\hline & Green consumption values & & & $0.567^{* *}$ & $0.702^{* *}$ \\
\hline \multirow{5}{*}{ UK sample } & $\begin{array}{l}\text { Receptivity to green } \\
\text { communication }\end{array}$ & & & & $0.496^{* *}$ \\
\hline & $\begin{array}{c}\text { Full scale (Pro-environmental } \\
\text { attitudes) }\end{array}$ & $0.569 * *$ & $0.799 * *$ & $0.818^{* *}$ & $0.800 * *$ \\
\hline & General pro-social attitudes & & $0.384^{* *}$ & $0.371^{* *}$ & $0.273^{* *}$ \\
\hline & Green consumption values & & & $0.516^{* *}$ & $0.661^{* *}$ \\
\hline & $\begin{array}{l}\text { Receptivity to green } \\
\text { communication }\end{array}$ & & & & $0.478^{* *}$ \\
\hline
\end{tabular}

Note: ** correlation significant at 0.01 level (two-tailed). Source: Own research.

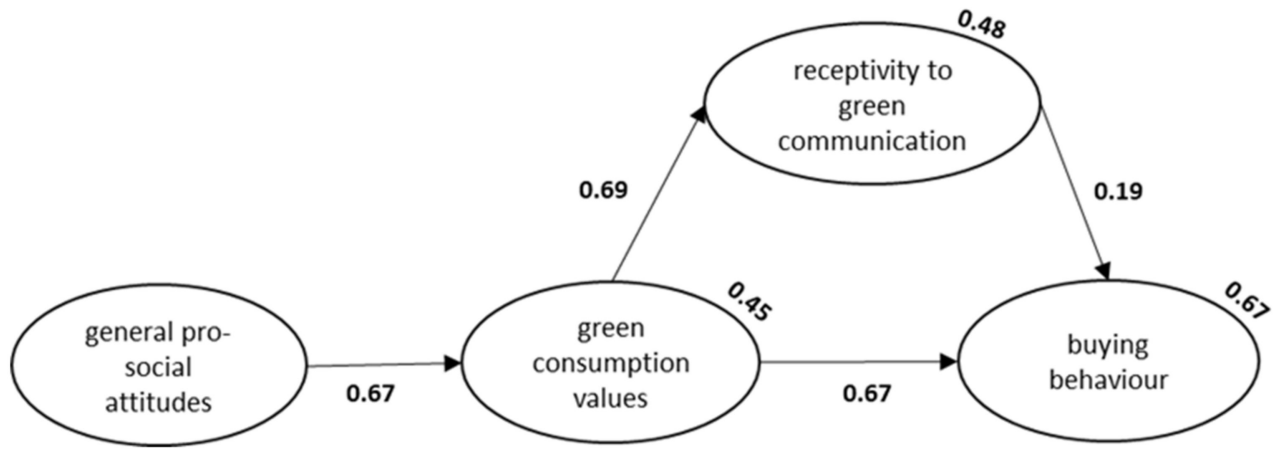

(a)

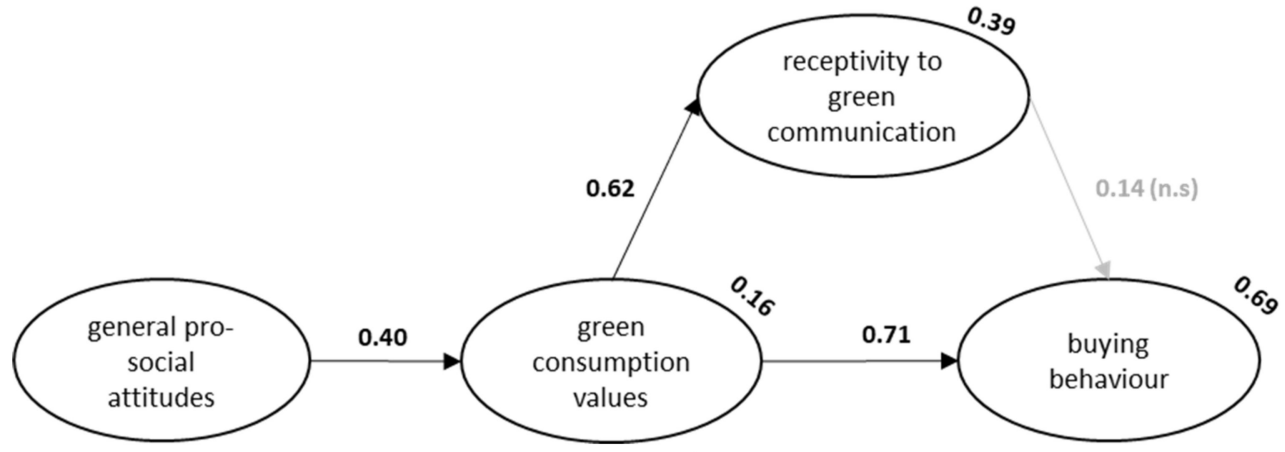

(b)

Figure 3. Model for testing green consumer behaviour (Model 1) (Source: Own elaboration based on [32]). (a) Replication-PL sample (Model 1-PL). (b) Replication-UK sample (Model 1-UK). Note: Estimates are placed next to the arrows. Statistically non-significant coefficients are given in grey. The R-squared measure is reported above the latent variable ellipse.

It should be noted that the model did not fully explain green consumption behaviour (buying behaviour variable in the model), and moreover, the coefficient of determination (R-squared) varied for the Polish and UK samples (Figure 3). For example, $45 \%$ of the variance of the green consumption values dimension could be explained by the intensity of general pro-social attitudes among Polish respondents, but only $16 \%$ of the variance was explained in the UK group. Additionally, in the case of the latent variable receptivity to green communication, a greater proportion of the variance in the Polish sample was explained by the green consumption values dimension than in the UK group. In both cases, buying over $30 \%$ of the variance of the behaviour dimension was explained by constructs 
other than those included in the model (receptivity to green communication and green consumption values).

The replication of the do Paço et al. [32] model manifested a relatively good fit to the data (Table 4), with better model fitting for the Polish than UK sample. This was partly an effect of the smaller size of the UK sample. The close fit probability level for both models was 0.000 , which is reasonable for large samples, and the chi-square/df relative measure was low enough. The fit to Polish sample data in terms of the RMSEA and SRMR was excellent. PCLOSE - the probability that the population RMSEA $<0.05$ - equalled 1 in this case (the $90 \%$ confidence interval endpoints were: $\mathrm{LO} 90=0.030, \mathrm{HI} 90=0.032$ ). The RMSEA was higher than the recommended value for the UK sample but still lay in the acceptable range below 0.08 . The standardised root mean squared residual (SRMR) for Model 1 was 0.051 in the PL sample and 0.067 in the UK one, showing good fit. The (A)GFI fit indices were slightly lower than required (especially in the UK sample). However, the CFI, NFI and TLI indices reached reference values, suggesting a good model fit.

Table 4. The Model 1 variance fit measures.

\begin{tabular}{|c|c|c|c|c|c|c|c|c|c|c|c|}
\hline & $\begin{array}{c}\text { Probability } \\
\text { Level }\end{array}$ & $\begin{array}{l}\text { Chi- } \\
\text { Square }\end{array}$ & DF & PCMIN/DF & GFI & AGFI & CFI & NFI & TLI & RMSEA & SRMR \\
\hline $\begin{array}{l}\text { Reference } \\
\text { values * }\end{array}$ & $>0.05$ & $\mathrm{~N} / \mathrm{A}$ & $\mathrm{N} / \mathrm{A}$ & $<5$ & $>0.95$ & $>0.9$ & $>0.9$ & $>0.9$ & $>0.9$ & $<0.08$ & $<0.08$ \\
\hline $\begin{array}{l}\text { Model } \\
1-\mathrm{PL}\end{array}$ & 0.000 & 1164.063 & 373 & 3.121 & 0.905 & 0.889 & 0.955 & 0.935 & 0.951 & 0.051 & 0.045 \\
\hline $\begin{array}{l}\text { Model } \\
1-U K\end{array}$ & 0.000 & 642.746 & 374 & 1.719 & 0.787 & 0.752 & 0.914 & 0.817 & 0.906 & 0.067 & 0.076 \\
\hline $\begin{array}{c}\text { Model } \\
\text { 1b-UK ** }\end{array}$ & 0.000 & 639.656 & 373 & 1.715 & 0.787 & 0.752 & 0.914 & 0.818 & 0.907 & 0.067 & 0.074 \\
\hline
\end{tabular}

* Reference values were taken from Hu and Bentler [107]. ** Model 1b-UK was analysed with the non-significant path between receptivity and green communication and with buying behaviour construct removed. Note: IBM AMOS 27 estimation. Source: Own research.

The analysis of the data (to provide an answer for RQ2) using the Mann-Whitney $\mathrm{U}$ test showed that Polish and British young people differed in the intensity of their proenvironmental attitudes. These differences were statistically significant at $p<0.01$ for most scale items except receptivity to green communication (Table 5). For general prosocial attitudes, the UK sample manifested a higher general level of the attitude's intensity than the PL sample. This was also valid for the majority of items in the dimension. No statistically significant differences applied exclusively to the following attitude: "It is important all people are happy."

In terms of green consumption values and buying behaviour, the UK population manifested a higher level of agreement with the statements with statistical significance for all statements at $p<0.01$. There were nine statements in the dimension "receptivity to green communication". The intensity of agreement was higher for the UK respondents than Polish ones in all these statements. However, for the following four statements, there was greater coherence, and the difference was not statistically significant at $p<0.01$ : "I avoid buying products that have excessive packaging"; "I respond favourably to brands that use green messages in their advertising"; "I am the kind of consumer who responds favourably when brands use green messages in their ads"; and "I think that green advertising is valuable". Figure 4 presents distributions of aggregate responses by dimension showing the greatest difference in shapes of distributions of the two samples in green consumption values and buying behaviour. In case of these dimensions, the distributions concerning the UK sample were strongly left-skewed in comparison with symmetric distributions of the PL sample. 
Table 5. Differences in agreement level between Polish and the UK respondents-pro-environmental attitudes scale.

\begin{tabular}{|c|c|c|c|}
\hline & Mean PL Sample & Mean UK Sample & $p$-Value \\
\hline \multicolumn{4}{|c|}{ General pro-social attitudes } \\
\hline 1. It is important that others are happy. & 4.06 & 4.34 & 0.000 \\
\hline 2. It is important to help someone who needs it. & 4.3 & 4.5 & 0.002 \\
\hline 3. I want to help others. & 4.13 & 4.44 & 0.000 \\
\hline 4. The well-being of others is important. & 4.13 & 4.47 & 0.000 \\
\hline 5. The needs of others are important. & 4.05 & 4.31 & 0.000 \\
\hline 6. It is important that all people are happy. & 4.09 & 4.18 & 0.324 \\
\hline
\end{tabular}

Green consumption values

1. It is important to me that the products I use do not harm the environment.

2. I consider the potential environmental impact of my

actions when making many of my decisions.

3. My purchase habits are affected by my concern for our environment.

4. I am concerned about wasting the resources of our planet.

5. I would describe myself as environmentally responsible.

6. I am willing to be inconvenienced in order to take actions that are more environmentally friendly.
3.78

3.5

4.18

0.000

3.59

3.93

0.000

4.08

3.84

0.004

3.47

4.42

3.83

0.000

0.000

3.42

4.03

0.000

\section{Receptivity to green communication}

\begin{tabular}{|c|c|c|c|}
\hline 1. I support brands that support the environment. & 3.47 & 4.07 & 0.000 \\
\hline $\begin{array}{l}\text { 2. I tend to pay attention to advertising messages that talk } \\
\text { about the environment. }\end{array}$ & 3.49 & 3.72 & 0.006 \\
\hline $\begin{array}{l}\text { 3. The use of green messages in ads affects my attitude } \\
\text { toward the ads. }\end{array}$ & 3.24 & 3.78 & 0.000 \\
\hline $\begin{array}{l}\text { 4. I respond favourably to brands that use green messages } \\
\text { in their advertising. }\end{array}$ & 3.58 & 3.72 & 0.124 \\
\hline $\begin{array}{l}\text { 5. I am the kind of consumer who responds favourably } \\
\text { when brands use green messages in their ads. }\end{array}$ & 3.51 & 3.63 & 0.273 \\
\hline 6. I think that green advertising is valuable. & 3.64 & 3.79 & 0.098 \\
\hline 7. I avoid buying products that have excessive packaging. & 3.84 & 3.74 & 0.279 \\
\hline $\begin{array}{l}\text { 8. I am the kind of consumer who is willing to purchase } \\
\text { products marketed as being green. }\end{array}$ & 3.23 & 3.88 & 0.000 \\
\hline 9. I tend to pay attention to green advertising messages. & 3.27 & 3.66 & 0.000 \\
\hline
\end{tabular}

Buying behaviour

\begin{tabular}{|c|c|c|c|}
\hline 1. I avoid buying products that have excessive packaging. & 3.57 & 4.02 & 0.000 \\
\hline $\begin{array}{l}\text { 2. When there is a choice, I choose the product that causes } \\
\text { the least pollution. }\end{array}$ & 3.6 & 4.05 & 0.000 \\
\hline 3. I have switched products/brands for ecological reasons. & 2.98 & 3.94 & 0.000 \\
\hline $\begin{array}{l}\text { 4. I make every effort to buy paper products made from } \\
\text { recycled paper. }\end{array}$ & 3.1 & 3.66 & 0.000 \\
\hline 5. I use environmentally friendly soaps and detergents. & 3.19 & 3.56 & 0.000 \\
\hline $\begin{array}{l}\text { 6. I have convinced members of my family or friends not to } \\
\text { buy products which are harmful to the environment. }\end{array}$ & 3 & 3.7 & 0.000 \\
\hline $\begin{array}{l}\text { 7. Whenever possible, I buy products packaged in reusable } \\
\text { containers. }\end{array}$ & 3.95 & 4.13 & 0.028 \\
\hline 8. I try to buy products that can be recycled. & 3.73 & 4.37 & 0.000 \\
\hline
\end{tabular}

Source: Own research. $n=973$ ( $n=812$ in the PL sample, $n=161$ in the UK sample).

These findings address RQ1 and RQ2. The scale was verified as equally valid for the Polish and UK cohorts (RQ1). Moreover, there were higher levels of pro-environmental attitudes in the UK as compared with Poland (RQ2). The postulated relationship between the purchase of organic food and intensity of the general pro-social attitudes was examined (RQ3). The results of Kruskal-Wallis test confirmed that people with a higher intensity of general pro-social attitudes in both surveyed groups were more likely to purchase organic food ( $p$-value $<0.001$ for the PL sample; $p$-value $=0.002$ for the UK sample). 


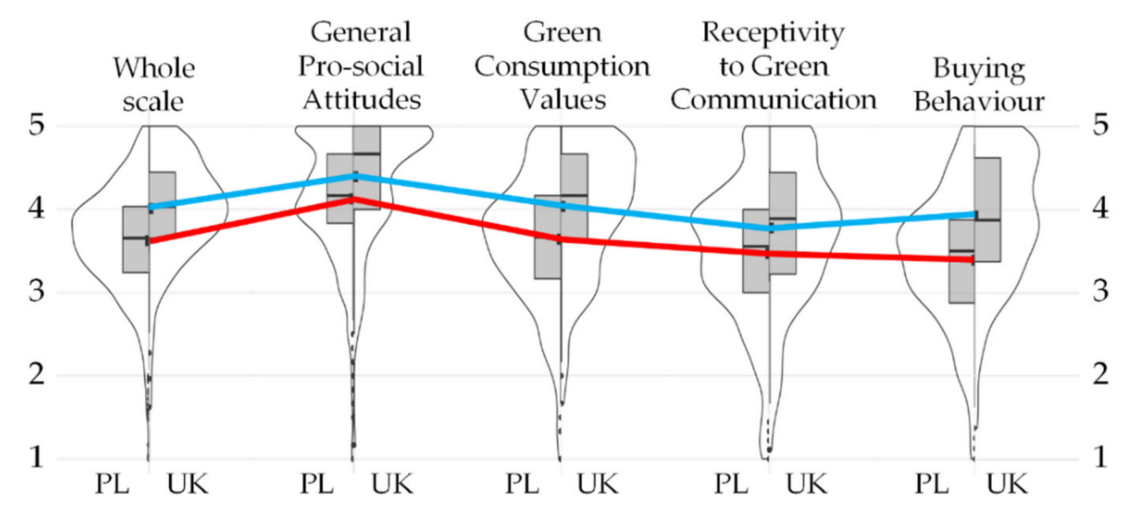

Figure 4. Pro-environmental attitudes intensity (by dimensions) for the PL (mean in red) and the UK (mean in blue) samples (Source: Own elaboration.). Note: Results were recalculated into the 5-point answer format. Subsequently, 5-point Likert scale was used where 1 denotes the lowest and 5 the highest intensity of attitudes.

The study also investigated whether the perception of organic food influenced the choice of organic food products (RQ4). The perception of organic food was verified on a unipolar semantic scale that examined the perception of such dimensions as healthiness, trustworthiness, quality, control system, authenticity, and safety. A grouping variable was prepared (bad/neutral/good perception). The purchase of organic food was also measured on a dichotomous nominal scale (declaration of whether the respondent buys or does not buy this type of food). Using the chi-squared test a significant relationship was shown between the variables in the Polish cohort $(p=0.000)$ and trends, but there was a non-significant relationship in the British one $(p=0.099)$. It means that the Polish respondents who had a positive perception of organic food were statistically more likely to buy organic food (Kruskal-Wallis test, $p=0.000$ ). In the UK, the association between the perception of organic food and purchasing behaviour was not observed to the same extent. These findings need to be explored further in future studies.

We now propose a new model for verifying the extent to which variables such as individual dimensions of pro-environmental attitudes and perception of organic food can explain the purchase of organic food (Figure 5). This model extends the do Paço et al. [32] approach, seeking an explanation of the introduced construct "organic food purchase" by similar variables to those used by do Paço et al. [32] and the added construct "organic food perception". All variables in Figure 5 are latent variables, as explained in the Materials and Methods section of the paper. Model 2 fitted the data well (Table 6), although the fit was better for the PL sample than the UK one.

In summary, Model 2 shows that neither the intensity of the pro-environmental attitude components nor the perception of organic food explained the consumers' choices to buy organic food to a satisfactory extent. Among Polish young consumers, only approximately $10 \%$ of the variance was explained, while among British young consumers this value was twice as high (22\%). Thus, nearly $80 \%$ (UK) or $90 \%$ (PL) of the variance was explained by factors other than the intensity of the pro-environmental attitude components and the perception of organic food. As a consequence, it is possible that organic food buying behaviour results from more complex cognitive and emotional processes not included in our model. 


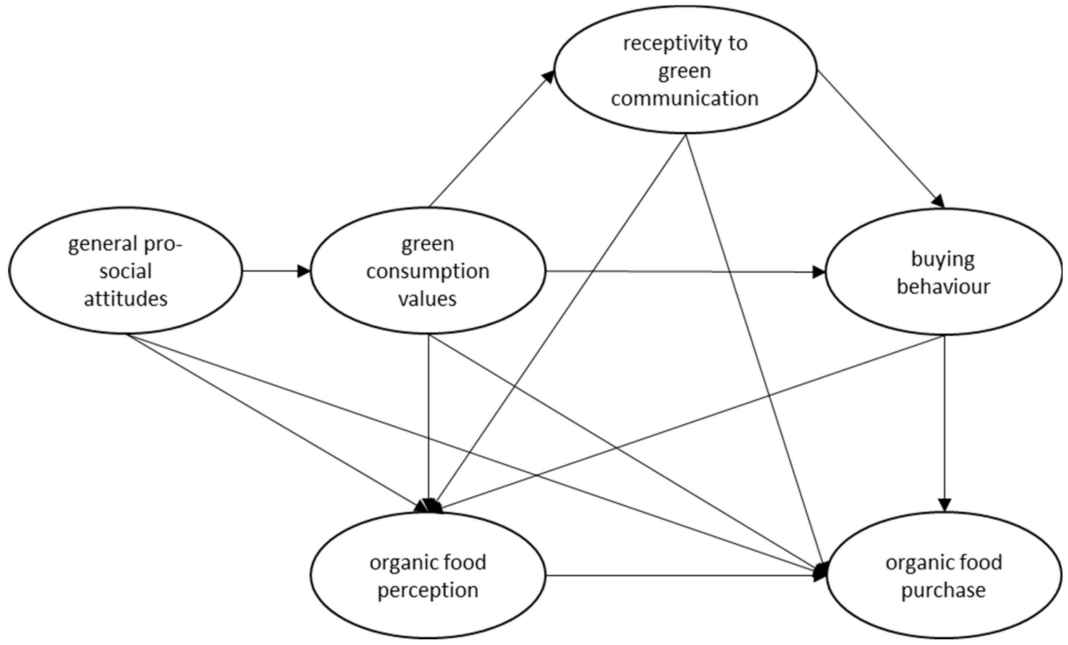

(a)

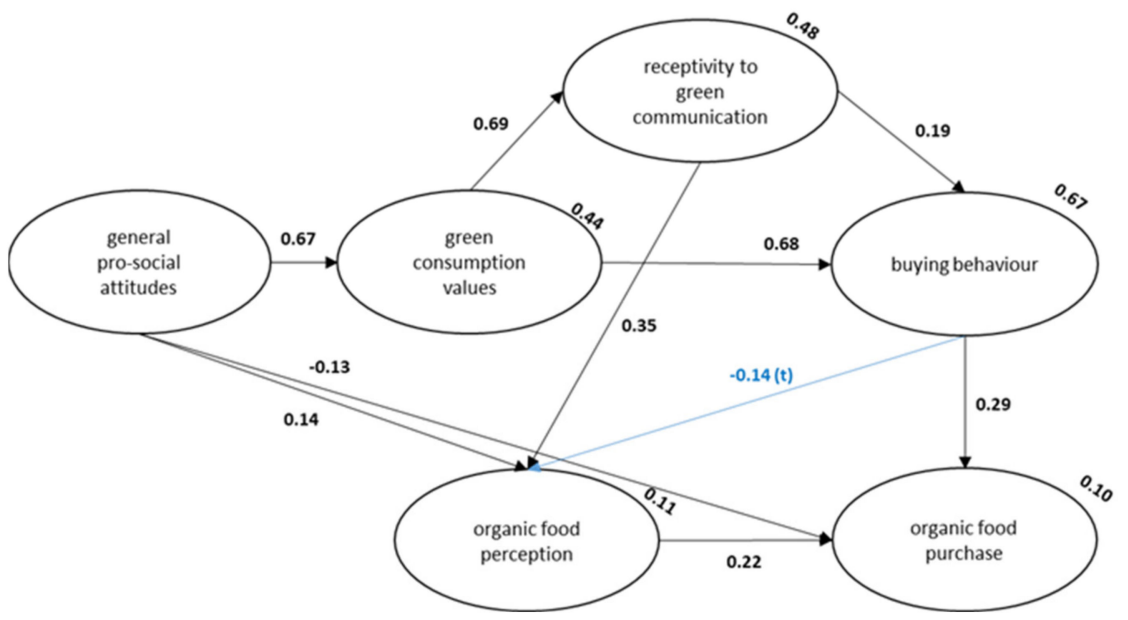

(b)

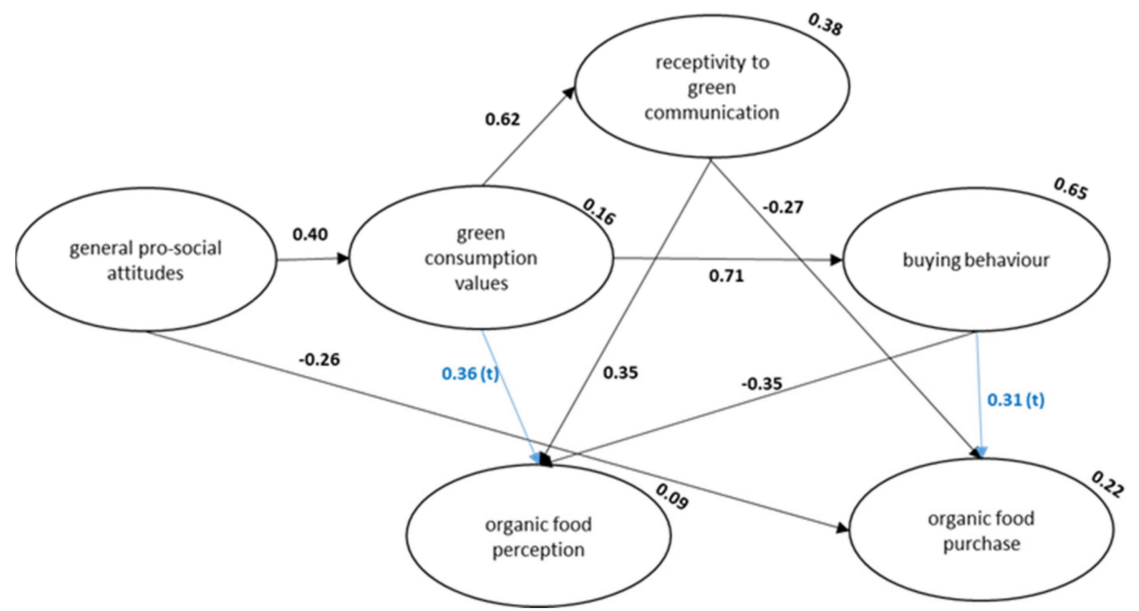

(c)

Figure 5. Extended organic food purchasing decision model-Model 2. (Source: Own elaboration with the use of IBM AMOS 27 estimation.) (a) Structure of the tested model. (b) Estimation resultsPL sample (Model 2-PL). (c) Estimation results-UK sample (Model 2-UK). Note 1: The models present only statistically significant estimates. Lack of an arrow between variables means that the estimation of the relationship was statistically insignificant. Note 2: Estimates are placed next to the arrows. $R^{2}$ is above the circle. Abbreviation ( $t$ ) indicates the statistical tendency (in blue). 
Table 6. Model 2 fit statistics.

\begin{tabular}{ccccccccccccc}
\hline & $\begin{array}{c}\text { Probability } \\
\text { Level }\end{array}$ & $\begin{array}{c}\text { Chi- } \\
\text { Square }\end{array}$ & DF & PCMIN/DF & GFI & AGFI & CFI & NFI & TLI & RMSEA & SRMR \\
\hline $\begin{array}{c}\text { Reference } \\
\text { values* } \\
\begin{array}{l}\text { Model } \\
2-P L\end{array}\end{array}$ & $>0.05$ & N/A & N/A & $<5$ & $>0.95$ & $>0.9$ & $>0.9$ & $>0.9$ & $>0.9$ & $<0.08$ & $<0.08$ \\
$\begin{array}{l}\text { Model } \\
\text { 2-UK }\end{array}$ & 0.000 & 1629.689 & 619 & 2.633 & 0.895 & 0.880 & 0.952 & 0.924 & 0.948 & 0.045 & 0.042 \\
\hline
\end{tabular}

${ }^{*}$ Reference values were taken from Hu and Bentler [107]. IBM AMOS 27 estimation. $n=973$. Source: Own research.

Different constructs were shown to exert a decisive impact on buying behaviour, with particular regard to the organic food market. In Poland, the formation of green consumption values was significantly influenced by general pro-social attitudes, whereas, in the UK, the importance of this dimension was much lower (Table 7) and a smaller proportion of the variance observed was explained. It is interesting to note that buying behaviour was negatively associated with the perception of organic food in both Model 2-PL and Model 2-UK, although more strongly in the UK group. Perhaps this issue is related to negative experiences following previous purchases of green food products or to factors that were not explored in this study, such as price or availability. Again, this constitutes an avenue for future research. With the UK sample, green consumption values were significantly positively associated with organic food purchasing decisions, rather than general pro-social attitudes, receptivity to green communication, or the perception of organic food (Table 7). In the PL sample, green consumption values and buying behaviour were associated with the purchase of organic food, and the perception of organic food was mainly influenced by receptivity to green communication.

Table 7. Standardised effects of variables used in Model 2.

\begin{tabular}{|c|c|c|c|c|c|c|}
\hline \multirow{2}{*}{ Standardised Effects } & \multirow{2}{*}{ Explained Variables } & \multicolumn{5}{|c|}{ Explanatory Variables } \\
\hline & & ATT & VAL & COMM & BEH & PERC \\
\hline \multicolumn{7}{|c|}{ PL sample } \\
\hline \multirow{5}{*}{ Standardised total effects } & VAL & 0.666 & 0.000 & 0.000 & 0.000 & 0.000 \\
\hline & COMM & 0.461 & 0.693 & 0.000 & 0.000 & 0.000 \\
\hline & $\mathrm{BEH}$ & 0.538 & 0.808 & 0.189 & 0.000 & 0.000 \\
\hline & PERC & 0.220 & 0.118 & 0.313 & -0.146 & 0.000 \\
\hline & PURCH & 0.071 & 0.254 & 0.116 & 0.256 & 0.199 \\
\hline \multirow{5}{*}{ Standardised direct effects } & VAL & 0.666 & 0.000 & 0.000 & 0.000 & 0.000 \\
\hline & COMM & 0.000 & 0.693 & 0.000 & 0.000 & 0.000 \\
\hline & $\mathrm{BEH}$ & 0.000 & 0.677 & 0.189 & 0.000 & 0.000 \\
\hline & PERC & 0.141 & 0.000 & 0.341 & -0.146 & 0.000 \\
\hline & PURCH & -0.126 & 0.000 & 0.000 & 0.285 & 0.199 \\
\hline \multirow{5}{*}{ Standardised indirect effects } & VAL & 0.000 & 0.000 & 0.000 & 0.000 & 0.000 \\
\hline & COMM & 0.461 & 0.000 & 0.000 & 0.000 & 0.000 \\
\hline & $\mathrm{BEH}$ & 0.538 & 0.131 & 0.000 & 0.000 & 0.000 \\
\hline & PERC & 0.079 & 0.118 & -0.028 & 0.000 & 0.000 \\
\hline & PURCH & 0.197 & 0.254 & 0.116 & -0.029 & 0.174 \\
\hline
\end{tabular}


Table 7. Cont

\begin{tabular}{|c|c|c|c|c|c|c|}
\hline \multirow{2}{*}{ Standardised Effects } & \multirow{2}{*}{ Explained Variables } & \multicolumn{5}{|c|}{ Explanatory Variables } \\
\hline & & ATT & VAL & COMM & BEH & PERC \\
\hline \multicolumn{7}{|c|}{ UK sample } \\
\hline \multirow{5}{*}{ Standardised total effects } & VAL & 0.402 & 0.000 & 0.000 & 0.000 & 0.000 \\
\hline & COMM & 0.256 & 0.635 & 0.000 & 0.000 & 0.000 \\
\hline & $\mathrm{BEH}$ & 0.327 & 0.812 & 0.000 & 0.000 & 0.000 \\
\hline & PERC & 0.081 & 0.201 & 0.000 & -0.364 & 0.000 \\
\hline & PURCH & -0.093 & 0.329 & -0.203 & 0.451 & 0.184 \\
\hline \multirow{5}{*}{ Standardised direct effects } & VAL & 0.402 & 0.000 & 0.000 & 0.000 & 0.000 \\
\hline & COMM & 0.000 & 0.635 & 0.000 & 0.000 & 0.000 \\
\hline & $\mathrm{BEH}$ & 0.000 & 0.812 & 0.000 & 0.000 & 0.000 \\
\hline & PERC & 0.000 & 0.497 & 0.000 & -0.364 & 0.000 \\
\hline & PURCH & -0.226 & 0.000 & -0.203 & 0.518 & 0.184 \\
\hline \multirow{5}{*}{ Standardised indirect effects } & VAL & 0.000 & 0.000 & 0.000 & 0.000 & 0.000 \\
\hline & COMM & 0.256 & 0.000 & 0.000 & 0.000 & 0.000 \\
\hline & $\mathrm{BEH}$ & 0.327 & 0.000 & 0.000 & 0.000 & 0.000 \\
\hline & PERC & 0.081 & -0.296 & 0.000 & 0.000 & 0.000 \\
\hline & PURCH & 0.132 & 0.329 & 0.000 & -0.067 & 0.000 \\
\hline
\end{tabular}

Note: The names of variables in the model are abbreviated. ATT = "general pro-social attitudes", VAL = "green consumption values", COMM = "receptivity to green communication", BEH = "buying behaviour", PERC = "organic food perception", PURCH = "organic food purchase". Source: Own research.

\section{Discussion and Concluding Thoughts}

Whilst the average spend on organic food products is low compared to other European countries, the UK is a country with a mature market for organic food [108,109], while London has a relatively more mature market than other regions [110]. Despite the organic food market being perceived as one of the most promising food market sectors in Poland [111], the Polish market for organic food is still immature, particularly due to poorly developed distribution channels [112]. Łuczka [112] identified the major barriers to the development of the organic food market in Poland, i.e., relatively high prices, legislator requirements, physical availability of some food products (e.g., fresh food), and a small offer of organic food products in the market. Many contextual factors, including prices of organic food, peer influence, and availability of organic food, may affect individual motivation, perception, and behavioural outcome. However, the most careful attention should be paid to drawing up a list of these contextual factors, and further research is needed in this area. Furthermore, contextual factors may have either direct or indirect impact on behaviour [113]. It has been proven before that low physical availability and limited economic accessibility of organic products are the main barriers to the growth of the organic food market in Poland [84,112].

Our study was designed to test and extend the model of do Paço et al. [32] for young consumers from the UK and Poland in order to evaluate its applicability in given generational cohorts and show differences between young consumers' attitudes and behaviour concerning organic food in Poland and the UK. The research confirmed that the scale proposed by do Paço et al. [32] can be used to assess the intensity of consumer attitudes. Moreover, it was proved that the model with dimensions proposed by do Paço et al. [32] retained good model fit in studies on young consumers in countries with different backgrounds regarding the tackling of pro-environmental issues (RQ1). Polish and UK young residents differed in terms of the intensity of pro-environmental attitudes (RQ2). It is noticeable that the UK cohort comprised more conscious green consumers than the Polish one. The UK cohort was also more homogeneous. In both the PL and the UK group, respondents with a higher intensity of the pro-environmental attitudes were more likely to decide to buy organic food (RQ3). Perception of organic food more strongly influenced the purchase of organic food among Polish than British young consumers (RQ4). However, it can be stated that the intensity of the pro-environmental attitude components and the 
perception of organic food did not explain the young consumers' purchases of organic food to a satisfactory extent in either country. This is in line with other studies, including the study by Pham et al. [114] that showed that environmental concern and food taste were limited in predicting attitudes towards organic food. They concluded that perceived barriers to the development of the organic food market include, i.e., high prices, poor availability, poor labelling, and reduced convenience.

The question arises as to whether limited buying behaviour for organic food in Poland and the UK, as attested by the data on per capita spending on organic food in these countries, is related to consumers' lack of knowledge of organic systems, issues around access, and affordability or to consumers' assessment of the level of sustainability derived by organic food systems. Other foods from alternative sources in the UK may instead be seen as alternatives for green consumption, e.g., regional food, local food, and domestic/home food products which are in direct competition in the marketplace with organic food products. Indeed, in a time where organic production is low yielding, this is at odds with concerns for making space for nature and regenerating natural biodiversity, if organic production is not perceived to deliver on this agenda. Our research results can help decision-makers in the food sector to make informed choices. As per capita consumption of organic food and antecedents of buying behaviour differ between European countries, it is crucial for each state and every company operating in a given area to develop its own national/business strategy. Due to the recognized differences between the UK and Polish organic food market, both manufacturers and retailers should develop marketing strategies tailored to the specificities of the countries in which they operate. There is still room for public awareness campaigns in Poland to improve consumers' knowledge of the organic food logo and of the benefits of organic production and consumption, but if other barriers persist, this alone will not drive an increase in organic food purchases. Reducing supply chain inefficiencies to improve the functioning of the organic food supply chain in Poland would be of value since the major barrier to the development of the organic food market has been the low availability of numerous organic products for the last decades. It seems that state intervention in the organic market mechanisms in Poland is both inevitable and necessary.

\section{Limitations}

It should be noted that the present research has certain limitations. First, the research was conducted during the COVID-19 pandemic when various restrictions on movement (lockdown) were in place in both countries. It is difficult to assess the extent to which the experience of this situation influenced respondents' answers and modified their purchase decisions. The pandemic also caused some consumers to return to their home country. It is most likely that a substantial number of such consumers lived in the surveyed countries for some time before the pandemic. That is why responses from people staying outside of the surveyed countries were not excluded from the analyses. Second, the Polish sample was significantly larger than the UK sample. A larger UK sample could have benefited the fit of the proposed model of organic food purchasing developed in the study (Model 2). Third, two groups of young consumers (mainly students) were surveyed; thus, the results could not be generalised to the entire Polish/British population. The items in the questionnaire were also of a declarative nature, which is a weakness of tools such as CAWI. However, it is difficult to conduct other surveys in the time of a pandemic.

Author Contributions: Conceptualization, A.K., M.R., M.B. and L.M.; methodology, A.K. and M.R.; investigation, M.B. and L.M.; data curation, M.R.; original draft preparation, A.K. and M.R.; review and editing, A.K., M.B., L.M., R.M. and M.R.; visualisation, M.R., R.M. and A.K.; supervision, A.K., L.M. and M.B.; project administration, M.B.; funding acquisition, M.B. All authors have read and agreed to the published version of the manuscript.

Funding: This research was funded by the National Science Centre, Poland, grant no. 2019/35/D/HS4/00801.

Institutional Review Board Statement: All subjects gave their informed consent for inclusion before they participated in the study. The study was conducted in accordance with the Declaration 
of Helsinki, and the protocol was approved by the Research Ethics Committee of Maria CurieSkłodowska University, Lublin, Poland, on 10 November 2020, and by the Research Ethics Review and Approvals Sub-Committee of Royal Agricultural University, UK, on 2 November 2020 (reference number 20202702-Manning).

Informed Consent Statement: Informed consent was obtained from all subjects involved in the study.

Data Availability Statement: The data that support the findings of this study are available on request from M.R.

Conflicts of Interest: The authors declare no conflict of interest.

\section{References}

1. Dhandra, T.K. Achieving triple dividend through mindfulness: More sustainable consumption, less unsustainable consumption and more life satisfaction. Ecol. Econ. 2019, 161, 83-90. [CrossRef]

2. Fischer, D.; Böhme, T.; Geiger, S.M. Measuring young consumers' sustainable consumption behaviour: Development and validation of the YCSCB scale. Young Consum. 2017, 18, 312-326. [CrossRef]

3. Liu, W.; Oosterveer, P.; Spaargaren, G. Promoting sustainable consumption in China: A conceptual framework and research review. J. Clean. Prod. 2016, 134, 13-21. [CrossRef]

4. Mont, O.; Neuvonen, A.; Lähteenoja, S. Sustainable lifestyles 2050: Stakeholder visions, emerging practices and future research. J. Clean. Prod. 2014, 63, 24-32. [CrossRef]

5. Bridgewater, P.; Guarino, E.; Thompson, R.M. Hydrology in the Anthropocene. In Encyclopedia of the Anthropocene; Dellasala, D.A., Goldstein, M.I., Eds.; Elsevier: Amsterdam, The Netherlands, 2018; pp. 87-92. [CrossRef]

6. Busch, J.; Engelmann, J. Cost-effectiveness of reducing emissions from tropical deforestation, 2016-2050. Environ. Res. Lett. 2018, 13, 015001. [CrossRef]

7. Fawzy, S.; Osman, A.I.; Doran, J.; Rooney, D.W. Strategies for mitigation of climate change: A review. Environ. Chem. Lett. 2020, 18, 2069-2094. [CrossRef]

8. Xie, H.; Zhang, Y.; Wu, Z.; Lv, T. A Bibliometric Analysis on Land Degradation: Current Status, Development, and Future Directions. Land 2020, 9, 28. [CrossRef]

9. Yao, L.; Li, X.; Li, Q.; Wang, J. Temporal and Spatial Changes in Coupling and Coordinating Degree of New Urbanization and Ecological-Environmental Stress in China. Sustainability 2019, 11, 1171. [CrossRef]

10. WHO. 2021. Climate Change and Human Health. Available online: https://www.who.int/globalchange/environment/en/ (accessed on 23 April 2021).

11. Cohen, M.J. Does the COVID-19 outbreak mark the onset of a sustainable consumption transition? Sustain. Sci. Pract. Policy 2020, 16, 1-3. [CrossRef]

12. United Nations. 1992. Agenda 21. Available online: https://sustainabledevelopment.un.org/content/documents/Agenda21.pdf (accessed on 23 April 2021).

13. Béné, C.; Oosterveer, P.; Lamotte, L.; Brouwer, I.D.; de Haan, S.; Prager, S.D.; Talsma, E.F.; Khoury, C.K. When food systems meet sustainability-Current narratives and implications for actions. World Dev. 2019, 113, 116-130. [CrossRef]

14. Willett, W.; Rockström, J.; Loken, B.; Springmann, M.; Lang, T.; Vermeulen, S.; Garnett, T.; Tilman, D.; DeClerck, F.; Wood, A.; et al. Food in the Anthropocene: The EAT-Lancet Commission on healthy diets from sustainable food systems. Lancet 2019, 393, 447-492. [CrossRef]

15. United Nations. 2015. Transforming Our World: The 2030 Agenda for Sustainable Development. Available online: https: //www.un.org/ga/search/view_doc.asp?symbol=A/RES/70/1\&Lang=E (accessed on 23 April 2021).

16. Regulation (EU) 2018/848 of the European Parliament and of the Council of 30 May 2018 on organic production and labelling of organic products and repealing Council Regulation (EC) No 834/2007 (OJ L 150, 14.6.2018, p. 1-92).

17. Kahawandala, N.; Peter, S.; Niwunhella, H. Profiling purchasing behaviour of Generation Z. In Proceedings of the 2020 International Research Conference on Smart Computing and Systems Engineering (SCSE), Colombo, Sri Lanka, 24 September 2020; pp. 155-160. [CrossRef]

18. Su, C.-H.; Tsai, C.-H.; Chen, M.-H.; Lv, W.Q. U.S. Sustainable Food Market Generation Z Consumer Segments. Sustainability 2019, 11, 3607. [CrossRef]

19. Naderi, I.; Van Steenburg, E. Me first, then the environment: Young Millennials as green consumers. Young Consum. 2018, 19, 280-295. [CrossRef]

20. Berkup, S.B. Working with Generations X and Y in Generation Z Period: Management of Different Generations in Business Life. Mediterr. J. Soc. Sci. 2014, 5, 218-229. [CrossRef]

21. Dimock, M. Defining Generations: Where Millennials End and Generation Z Begins. Pew Research Center. 2019. Available online: https:/ / www.pewresearch.org/fact-tank/2019/01/17/where-millennials-end-and-generation-z-begins / (accessed on 25 February 2021). 
22. Ivanova, O.; Flores-Zamora, J.; Khelladi, I.; Ivanaj, S. The generational cohort effect in the context of responsible consumption. Manag. Decis. 2019, 57, 1162-1183. [CrossRef]

23. Viswanathan, V.; Jain, V. A dual-system approach to understanding "generation Y" decision making. J. Consum. Mark. 2013, 30, 484-492. [CrossRef]

24. Prasad, S.; Garg, A.; Prasad, S. Purchase decision of generation Y in an online environment. Mark. Intell. Plan. 2019, 37, $372-385$. [CrossRef]

25. Di Giulio, A.; Fuchs, D. Sustainable Consumption Corridors: Concept, Objections, and Responses. GAIA-Ecol. Perspect. Sci. Soc. 2014, 23, 184-192. [CrossRef]

26. Ajzen, I. From intentions to actions: A theory of planned behaviour. In Action Control: From Cognition to Behaviour; Kuhl, J., Beckmann, J., Eds.; Springer: New York, NY, USA, 1985; pp. 11-39. [CrossRef]

27. Ajzen, I. The Theory of Planned Behaviour. Organ. Behav. Hum. Decis. Process. 1991, 50, 179-211. [CrossRef]

28. Fishbein, M.; Ajzen, I. Belief, Attitude, Intention, and Behaviour: An Introduction to Theory and Research; Addison-Wesley: Reading, MA, USA, 1975.

29. Straughan, R.D.; Roberts, J.A. Environmental segmentation alternatives: A look at green consumer behavior in the new millennium. J. Consum. Mark. 1999, 16, 558-575. [CrossRef]

30. Stern, P.C.; Dietz, T.; Abel, T.; Guagnano, G.A.; Kalof, L. A value-belief-norm theory of support for social movements: The case of environmentalism. Hum. Ecol. Rev. 1999, 6, 81-97.

31. Davari, A.; Iyer, P.; Strutton, D. Investigating Moral Links Between Religiosity, Altruism, and Green Consumption. J. Nonprofit Public Sect. Mark. 2017, 29, 385-414. [CrossRef]

32. Do Paço, A.; Shiel, C.; Alves, H. A new model for testing green consumer behaviour. J. Clean. Prod. 2019, 207, 998-1006. [CrossRef]

33. Ashraf, M.A.; Joarder MH, R.; Ratan, S.R.A. Consumers' anti-consumption behaviour toward organic food purchase: An analysis using SEM. Br. Food J. 2018, 121, 104-122. [CrossRef]

34. Rahman, K.M.; Noor, D.A.M. Evaluating Gaps in Consumer Behaviour Research on Organic Foods: A Critical Literature Review under Bangladesh Context. J. Mark. Cons. Behav. Emerg. Mark. 2016, 1, 42-50. [CrossRef]

35. Sobhanifard, Y.; Griffith, C. Hybrid modelling of the consumption of organic foods in Iran using exploratory factor analysis and an artificial neural network. Br. Food J. 2018, 120, 44-58. [CrossRef]

36. Jungbluth, N.; Tietje, O.; Scholz, R. Food purchases: Impacts from the consumers' point of view investigated with a modular LCA. Int. J. Life Cycle Assess. 2000, 5, 134-142. [CrossRef]

37. Hansmann, R.; Baur, I.; Binder, C.R. Increasing organic food consumption: An integrating model of drivers and barriers. J. Clean. Prod. 2020, 275, 123058. [CrossRef]

38. Lorenz, K.; Lal, R. Chapter Three-Environmental Impact of Organic Agriculture. In Advances in Agronomy; Sparks, D.L., Ed.; Academic Press: Cambridge, MA, USA; Elsevier: Oxford, UK, 2016; Volume 139, pp. 99-152. [CrossRef]

39. Muller, A.; Schader, C.; Scialabba, N.E.H.; Brüggemann, J.; Isensee, A.; Erb, K.H.; Smith, P.; Klocke, P.; Leiber, F.; Stolze, M.; et al. Strategies for feeding the world more sustainably with organic agriculture. Nat. Commun. 2017, 8, 1290. [CrossRef] [PubMed]

40. Treu, H.; Nordborg, M.; Cederberg, C.; Heuer, T.; Claupein, E.; Hoffmann, H.; Berndes, G. Carbon footprint sand land use of conventional and organic diets in Germany. J. Clean. Prod. 2017, 161, 127-142. [CrossRef]

41. Tuomisto, H.L.; Hodge, I.D.; Riordan, P.; Macdonald, D.W. Does organic farming reduce environmental impacts?-A metaanalysis of European research. J. Environ. Manag. 2012, 112, 309-320. [CrossRef]

42. Meemken, E.-M.; Qaim, M. Organic agriculture, food security, and the environment. Annu. Rev. Resour. Econ. 2018, 10, 39-63. [CrossRef]

43. IFOAM Organics International. How Organic Agriculture Helps Achieve Sustainable Development Goals. 2021. Available online: https://www.ifoam.bio/sites/default/files/2020-05/oasdgs_web.pdf (accessed on 29 April 2021).

44. Notarnicola, B.; Tassielli, G.; Renzulli, P.A.; Castellani, V.; Sala, S. Environmental impacts of food consumption in Europe. J. Clean. Prod. 2017, 140, 753-765. [CrossRef]

45. Seufert, V.; Ramankutty, N.; Foley, J.A. Comparing the yields of organic and conventional agriculture. Nature 2012, 485, 229-232. [CrossRef]

46. Goodland, R. The Concept of Environmental Sustainability. Annu. Rev. Ecol. Syst. 1995, 26, 1-24. [CrossRef]

47. Ottman, J.; Terry, V. Strategic marketing of greener products. J. Sustain. Prod. Des. 1998, 5, 53-57.

48. Rana, J.; Paul, J. Consumer behaviour and purchase intention for organic food: A review and research agenda. J. Retail. Consum. Serv. 2017, 38, 157-165. [CrossRef]

49. Willer, H.; Trávníček, J.; Meier, C.; Schlatter, B. (Eds.) The World of Organic Agriculture. Statistics and Emerging Trends 2021; Research Institute of Organic Agriculture (FiBL), Frick, and IFOAM-Organics International: Bonn, Germany, 2021.

50. Thogersen, J. Country differences in sustainable consumption: The case of organic food. J. Macromark. 2010, 30, 171-185. [CrossRef]

51. FiBL Statistics. Interactive Online Database, 2021. Available online: https://statistics.fibl.org/data.html (accessed on 10 May 2021).

52. Ottman, J.A. Green Marketing: Challenges and Opportunities for the New Marketing Age; NTC Business Books: New York, NY, USA, 1993.

53. Perera, C.; Auger, P.; Klein, J. Green Consumption Practices Among Young Environmentalists: A Practice Theory Perspective. J. Bus. Ethics 2018, 152, 843-864. [CrossRef] 
54. Brochado, A.; Teiga, N.; Oliveira-Brachado, F. The ecological conscious consumer behaviour: Are the activist different? Int. J. Consum. Stud. 2017, 41, 138-146. [CrossRef]

55. Quoquab, F.; Mohammad, J.; Sukari, N.N. A multiple-item scale for measuring "sustainable consumption behaviour" construct. Asia Pac. J. Mark. Logist. 2019, 31, 791-816. [CrossRef]

56. Tamuliene, V.; Kazlauskiene, E.; Pilelienè, L. Ecologically-Conscious Consumer Purchases in Lithuania. Montenegrin J. Econ. 2016, $12,87-96$.

57. Zhang, X.; Dong, F. Why Do Consumers Make Green Purchase Decisions? Insights from a Systematic Review. Int. J. Environ. Res. Public Health 2020, 17, 6607. [CrossRef]

58. Chaudhary, R.; Bisai, S. Factors influencing green purchase behaviour of millennials in India. Manag. Environ. Qual. 2018, 29, 798-812. [CrossRef]

59. Suki, N.M.; Suki, N.M. Examination of peer influence as a moderator and predictor in explaining green purchase behaviour in a developing country. J. Clean. Prod. 2019, 228, 833-844. [CrossRef]

60. Spielmann, N. Green is the New White: How Virtue Motivates Green Product Purchase. J. Bus. Ethics 2021, 173, 759-776. [CrossRef]

61. Osgood, J.M.; Muraven, M. Self-Control Depletion Does not Diminish Attitudes about Being Prosocial but Does Diminish Prosocial Behaviours. Basic Appl. Soc. Psychol. 2015, 37, 68-80. [CrossRef]

62. Baudry, J.; Péneau, S.; Allès, B.; Touvier, M.; Hercberg, S.; Galan, P.; Amiot, M.-J.; Lairon, D.; Méjean, C.; Kesse-Guyot, E. Food Choice Motives When Purchasing in Organic and Conventional Consumer Clusters: Focus on Sustainable Concerns (The NutriNet-Santé Cohort Study). Nutrients 2017, 9, 88. [CrossRef]

63. Ghali-Zinoubi, Z.; Toukabri, M. The antecedents of the consumer purchase intention: Sensitivity to price and involvement in organic product: Moderating role of product regional identity. Trends Food Sci. Technol. 2019, 90, 175-179. [CrossRef]

64. Ghvanidze, S.; Velikova, N.; Dodd, T.H.; Oldewage-Theron, W. Consumers' environmental and ethical consciousness and the use of the related food products information: The role of perceived consumer effectiveness. Appetite 2016, 107, 311-322. [CrossRef]

65. Grunert, K.G.; Hieke, S.; Wills, J. Sustainability labels on food products: Consumer motivation, understanding and use. Food Policy 2014, 44, 177-189. [CrossRef]

66. Katt, F.; Meixner, O. A systematic review of drivers influencing consumer willingness to pay for organic food. Trends Food Sci. Technol. 2020, 100, 374-388. [CrossRef]

67. Yarimoglu, E.; Binboga, G. Understanding sustainable consumption in an emerging country: The antecedents and consequences of the ecologically conscious consumer behaviour model. Bus. Strategy Environ. 2019, 28, 642-651. [CrossRef]

68. Testa, F.; Sarti, S.; Frey, M. Are green consumers really green? Exploring the factors behind the actual consumption of organic food products. Bus. Strategy Environ. 2019, 28, 327-338. [CrossRef]

69. Biswas, A.; Roy, M. Green products: An exploratory study on the consumer behaviour in emerging economies of the east. J. Clean. Prod. 2015, 87, 463-468. [CrossRef]

70. Alagarsamy, S.; Mehrolia, S.; Mathew, S. How Green Consumption Value Affects Green Consumer Behaviour: The Mediating Role of Consumer Attitudes Towards Sustainable Food Logistics Practices. Vision 2021, 25, 65-76. [CrossRef]

71. Haws, K.L.; Winterich, K.P.; Naylor, R.W. Seeing the world through GREEN-tinted glasses: Green consumption values and responses to environmentally friendly products. J. Consum. Psychol. 2014, 24, 336-354. [CrossRef]

72. Groening, C.; Sarkis, J.; Zhu, Q. Green marketing consumer-level theory review: A compendium of applied theories and further research directions. J. Clean. Prod. 2018, 172, 1848-1866. [CrossRef]

73. Kumar, P. Intents of green advertisements. Asia-Pac. J. Mark. Logist. 2017, 29, 70-79. [CrossRef]

74. Alniacik, U.; Yilmaz, C. The Effectiveness of Green Advertising: Influences of Claim Specificity, Product's Environmental Relevance and Consumers' Pro-environmental Orientation. Amfiteatru Econ. 2012, 14, $207-222$.

75. Bailey, A.A.; Mishra, A.; Tiamiyu, M.F. Green advertising receptivity: An initial scale development process. J. Mark. Commun. 2014, 22, 327-345. [CrossRef]

76. Park, J.S.; Lee, J. Segmenting green consumers in the United States: Implications for green marketing. J. Promot. Manag. 2014, 20, 571-589. [CrossRef]

77. Sarkar, J.G.; Sarkar, A.; Yadav, R. Brand it green: Young consumers' brand attitudes and purchase intentions toward green brand advertising appeals. Young Consum. 2019, 20, 190-207. [CrossRef]

78. Cerri, J.; Testa, F.; Rizzi, F. The more I care, the less I will listen to you: How information, environmental concern and ethical production influence consumers' attitudes and the purchasing of sustainable products. J. Clean. Prod. 2018, 175, 343-353. [CrossRef]

79. Rees, W.; Tremma, O.; Manning, L. Sustainability cues on packaging: The influence of recognition on purchasing behaviour. J. Clean. Prod. 2019, 235, 841-853. [CrossRef]

80. Torelli, R.; Balluchi, F.; Lazzini, A. Greenwashing and environmental communication: Effects on stakeholders' perceptions. Bus. Strategy Environ. 2020, 29, 407-421. [CrossRef]

81. Kumar, P.; Ghodeswar, B.M. Factors affecting consumers' green product purchase decisions. Mark. Intell. Plan. 2015, 33, 330-347. [CrossRef]

82. Thamthanakoon, N.; Huang, I.Y.; Eastham, J.; Ward, S.; Manning, L. Factors driving Thailand rice farmer decision-making in the choice of marketing channel. Br. Food J. 2021, 1-19, ahead of print. [CrossRef] 
83. Kushwah, S.; Dhir, A.; Sagar, M.; Gupta, B. Determinants of organic food consumption. A systematic literature review on motives and barriers. Appetite 2019, 143, 104402. [CrossRef]

84. Bryła, P. Organic food consumption in Poland: Motives and barriers. Appetite 2016, 105, 737-746. [CrossRef]

85. Zámková, M.; Rojík, S.; Pilař, L.; Chalupová, M.; Prokop, M.; Stolín, R.; Dziekański, P.; Maitah, M. Customer Preferences for Organic Agriculture Produce in the Czech Republic: 2016 and 2019. Agriculture 2021, 11, 968. [CrossRef]

86. Massey, M.; O'Cass, A.; Otahal, P. A meta-analytic study of the factors driving the purchase of organic food. Appetite 2018, 125, 418-427. [CrossRef]

87. Manning, L.; Kowalska, A. Considering Fraud Vulnerability Associated with Credence-Based Products Such as Organic Food. Foods 2021, 10, 1879. [CrossRef]

88. Koklic, M.K.; Golob, U.; Podnar, K.; Zabkar, V. The interplay of past consumption, attitudes and personal norms in organic food buying. Appetite 2019, 137, 27-34. [CrossRef]

89. Nuttavuthisit, K.; Thøgersen, J. The importance of consumer trust for the emergence of a market for green products: The case of organic food. J. Bus. Ethics 2017, 140, 323-337. [CrossRef]

90. Rana, J.; Paul, J. Health motive and the purchase of organic food: A meta-analytic review. Int. J. Consum. Stud. 2020, 44, 162-171. [CrossRef]

91. Rizzo, G.; Borrello, M.; Dara Guccione, G.; Schifani, G.; Cembalo, L. Organic Food Consumption: The Relevance of the Health Attribute. Sustainability 2020, 12, 595. [CrossRef]

92. Śmiglak-Krajewska, M.; Wojciechowska-Solis, J. Consumer versus Organic Products in the COVID-19 Pandemic: Opportunities and Barriers to Market Development. Energies 2021, 14, 5566. [CrossRef]

93. Hansen, T.; Sørensen, M.I.; Eriksen, M.-L.R. How the interplay between consumer motivations and values influences organic food identity and behaviour. Food Policy 2017, 74, 39-52. [CrossRef]

94. Hurtado-Barroso, S.; Tresserra-Rimbau, A.; Vallverdu-Queralt, A.; Lamuela-Raventos, R.M. Organic food and the impact on human health. Crit. Rev. Food Sci. Nutr. 2017, 59, 704-714. [CrossRef]

95. Di Renzo, L.; De Lorenzo, A.; Merra, G.; Gualtieri, P. Comment on: “A Systematic Review of Organic Versus Conventional Food Consumption: Is There a Measurable Benefit on Human Health? Nutrients 2020, 12, 7". Nutrients 2020, 12, 696. [CrossRef] [PubMed]

96. Popa, M.E.; Mitelut, A.C.; Popa, E.E.; Stan, A.; Popa, V.I. Organic foods contribution to nutritional quality and value. Trends Food Sci. Technol. 2019, 84, 15-18. [CrossRef]

97. Smith-Spangler, C.; Brandeau, M.L.; Hunter, G.E.; Bavinger, J.C.; Pearson, M.; Eschbach, P.J.; Sundaram, V.; Liu, H.; Schirmer, P.; Stave, C.; et al. Are organic foods safer or healthier than conventional alternatives?: A systematic review. Ann Intern Med. 2012, 157, 348-366, Erratum in Ann Intern Med. 2012, 157, 680; Erratum in Ann Intern Med. 2012, 157, 532. [CrossRef] [PubMed]

98. Ballew, M.; Marlon, J.; Rosenthal, S.; Gustafson, A.; Kotcher, J.; Maibach, E.; Leiserowitz, A. Do Younger Generations Care More about Global Warming? Yale Program on Climate Change Communication: New Haven, CT, USA, 2019.

99. Kanchanapibul, M.; Lacka, E.; Wang, X.; Chan, K. An empirical investigation of green purchase behaviour among the young generation. J. Clean. Prod. 2014, 66, 528-536. [CrossRef]

100. Allison, P.D. Missing data techniques for structural equation modeling. J. Abnorm. Psychol. 2003, 112, 545-557. [CrossRef]

101. Buhi, E.R.; Goodson, P.; Neilands, T.B. Out of sight, not out of mind: Strategies for handling missing data. Am. J. Health Behav. 2008, 32, 83-92. [CrossRef]

102. Little, R.J.A.; Rubin, D.B. Statistical Analysis with Missing Data; Wiley: New York, NY, USA, 1987.

103. Doorn, J.; Verhoef, P.C. Drivers of and Barriers to Organic Purchase Behaviour. J. Retail. 2015, 91, 436-450. [CrossRef]

104. Hair, J.F.; Black, W.C.; Babin, B.J.; Anderson, R.E. Multivariate Data Analysis: Global Edition; Prentice Hall: Upper Saddle River, NJ, USA, 1998.

105. Sturge, G. Migration Statistics. Briefing Paper Number CBP06077, 27 April 2021. Available online: https://researchbriefings.files. parliament.uk/documents/SN06077/SN06077.pdf (accessed on 9 November 2021).

106. Eurostat. Migration and Migrant Population Statistics, 2021. Available online: https://ec.europa.eu/eurostat/statisticsexplained /index.php?title=Migration_and_migrant_population_statistics (accessed on 9 November 2021).

107. Hu, L.T.; Bentler, P.M. Cutoff criteria for fit indexes in covariance structure analysis: Conventional criteria versus new alternatives. Struct. Equ. Model. Multidiscip. J. 1999, 6, 1-55. [CrossRef]

108. Chehtman, A.; Wolf, A. Health, Sustainability and New Priorities Drive Organic Food Sales. 2021. Available online: https: //blog.euromonitor.com/health-sustainability-and-new-priorities-drive-organic-food-sales/ (accessed on 19 July 2021).

109. Von Meyer-Höfer, M.; von der Wense, V.; Padilla Bravo, C.; Spiller, A. Mature and Emerging Organic Markets: Modelling Consumer Attitude and Behaviour with Partial Least Square Approach. GlobalFood Discussion Papers 2013, 26. GeorgAugustUniversität Göttingen, Research Training Group (RTG) 1666-GlobalFood: Göttingen. Available online: https://www.econstor. eu/bitstream/10419/90621/1/GlobalFood_DP26.pdf (accessed on 19 July 2021).

110. Zhao, J.; Dou, X. A Study of British Organic Food Market. In Proceedings of the 9th International Conference on Education and Social Science, Shenyang, China, 29-31 March 2019; pp. 1048-1058. [CrossRef]

111. Kobuszynska, M. Organic Market in Poland. Available online: https://apps.fas.usda.gov/newgainapi/api/report/ downloadreportbyfilename?filename=Organic\%20Market\%20in\%20Poland_Warsaw_Poland_4-10-2017.pdf (accessed on 19 July 2021). 
112. Łuczka, W. Demand factors of development of the organic food market-A review of Polish research. Ann. Pol. Assoc. Agric. Agribus. Econ. 2019, 21, 260-276. [CrossRef]

113. Biswas, A.; Roy, M. Leveraging factors for sustained green consumption behaviour based on consumption value perceptions: Testing the structural model. J. Clean. Prod. 2015, 95, 332-340. [CrossRef]

114. Pham, T.H.; Nguyen, T.N.; Phan, T.T.H.; Nguyen, N.T. Evaluating the purchase behaviour of organic food by young consumers in an emerging market economy. J. Strateg. Mark. 2019, 27, 540-556. [CrossRef] 